\title{
TINDAK TUTUR DIREKTIF MAHASISWA MILENIAL DAN DOSEN DALAM GRUP WHATSAPP
}

\author{
Veni Nurpadillah ${ }^{1 凶}$ \\ ${ }^{1}$ Institut Agama Islam Negeri (IAIN) Syekh Nurjati Cirebon \\ 1veni_nurpadillah@syekhnurjati.ac.id
}

\begin{abstract}
Speech acts are the basis for the analysis of other pragmatic topics, directive speech acts are speech acts that have the potential to threaten the self-image of the speech actor. This threat can be addressed, both to speakers and speech partners. Speakers' self-image can fall if the command is not noticed by the speech partner, speech is not only heard verbally, directive speech can also be seen through conversations via WhatsApp. Millennial generation student conversations with lecturers can be known in the whatsapp group, which includes millennial students and lecturers. Millennial students feel more comfortable exchanging information on whatsapp groups because it's faster. Lecturers also feel more effective in sharing information, giving assignments because it will be read by all students. So that from the whatsapp group can be seen directive speech acts from lecturers and students.
\end{abstract}

Keywords: directive speech, whatsapp group, millennial students

Abstrak : Tindak tutur merupakan dasar bagi analisis topik-topik pragmatik lain, tindak tutur direktif merupakan tindak tutur yang berpotensi mengancam citra diri pelaku tutur. Keterancaman ini dapat tertuju, baik kepada penutur maupun mitra tutur. Citra diri penutur dapat jatuh jika perintahnya tidak diperhatikan oleh mitra tutur, tuturan tidak hanya didengar secara verbal, tuturan direktif juga dapat terlihat melalui percakapan melalui whatsapp. Percakapan mahasiswa generasi milenial terhadap dosen dapat diketahui dalam grup whatsapp yang didalamnya beranggotakan mahasiswa milenial dan dosen. Mahasiswa milenial merasa lebih nyaman jika bertukar informasi di grup whatsapp karena lebih cepat. Dosen juga merasa lebih efektif membagikan informasi, memberi tugas karena akan terbaca oleh semua mahasiwa. Sehingga dari grup whatsapp tersebut dapat terlihat tindak tutur direktif dari dosen maupun mahasiswa.

Kata Kunci : tindak tutur direktif, grup whatsapp, mahasiwa milenial 
Volume 1, Nomor 2, Juli 2019

ISSN 2655-3031 (P), 2655-7851 (O)

\section{Pendahuluan}

Komunikasi menjadi bagian penting dalam kehidupan manusia. Hal ini dikarenakan manusia merupakan makhluk sosial yang memerlukan orang lain dalam kesehariannya. Bentuk komunikasi dilakukan untuk menjalin hubungan dengan piha tertentu (Eliya, 2017:207). Komunikasi adalah jembatan penghubung sehingga antarindividu dapat saling mengungkapkan ide maupun pemikiran tentang sesuatu. Dalam perwujudannya, komunikasi tidak terlepas dari bahasa sebagai alat komunikasi. Melalui bahasa, ide-ide ataupun pemikiran seseorang akan tersampaikan dengan jelas kepada orang lain.

Penggunaan bahasa dalam komunikasi individu memunculkan istilah tuturan, penutur, dan mitra tutur. Tuturan adalah apa ide, gagasan, maupun pendapat berbentuk kalimat-kalimat ujaran yang disampaikan seseorang kepada orang lain. Di sisi lain, penutur merupakan orang atau pihak yang menyampaikan ide maupun gagasan kepada orang lain. Sementara itu, mitra tutur bisa diartikan sebagai pihak yang menjadi lawan bicara penutur.

Adanya tuturan di antara penutur dan mitra tutur selanjutnya melahirkan istilah tindak tutur. Menurut Rustono (1999: 33), tindak tutur atau tindak ujar (speech act) merupakan entitas yang bersifat sentral dalam pragmatik sehingga bersifat pokok. Tindak tutur merupakan dasar bagi analisis topik-topik pragmatik lain, seperti praanggapan, perikutan, implikatur percakapan, prinsip kerja sama, dan prinsip kesantunan.

Tindak tutur menurut Searle (dalam Saparina, 2012: 2) terbagi atas lima jenis, yaitu tindak representatif, direktif, ekspresif, komisif, dan deklarasi. Berkaitan dengan hal tersebut, pembahasan dalam penelitian ini akan terfokus pada tindak tutur direktif. Tindak tutur direktif dapat terlihat dalam percakapan antara dosen dan mahasiwa milenial melalui grup whatsapp.

Generasi Milenial sangat mahir dalam teknologi, karena lahir pada saat TV berwarna, handphone dan internet sudah ada, dan tentu mempunyai beberapa kebiasaan dan karakter tersendiri dari generasi sebelumnya. Menurut survei, rata-rata generasi ini hanya bisa bertahan jauh dari gadget selama 23 menit. Seperti yang kita lihat saat ini, ketika mahasiswa berkumpul, bukan sibuk ngobrol, tapi sibuk update status sambil scroll akun medsos, termasuk membuka whatsapp dan bertukar informasi mengenai perkuliahan melalui grup whatsapp karena dirasa lebih efektif. Percakapan mahasiswa generasi milenial terhadap dosen dapat diketahui dalam grup whatsapp yang didalamnya beranggotakan mahasiswa milenial dan dosen karena mahasiswa Milenial merasa lebih nyaman jika bertukar informasi di grup whatsapp karena lebih cepat. Mereka marasa lebih efektif jika bertanya atau menjawab di grup daripada membaca pengumuman yang sudah dibuat oleh pihak kampus. Perbincangan di dalam grup whatsapp antara mahasiswa dengan mahasiswa ataupun dengan dosen pun lebih santai dan tidak formal, seolah antara dosen dan mahasiswa tidak ada jarak untuk saling berbalas obrolan. Sehingga dosen lebih sering membagikan informasi serta memberi tugas melalui grup whatsapp karena akan terbaca oleh semua mahasiwa. Sehingga dari grup whatsapp tersebut dapat terlihat tindak tutur direktif dari dosen maupun mahasiswa.

Bagian pembahasan dalam penelitian ini, meliputi: pengertian tindak tutur direktif, jenis-jenis tindak tutur direktif, dan generasi milenial.

Ada beberapa pendapat berkaitan dengan pengertian tindak tutur direktif. Menurut Searle (dalam Etikasari, 2012: 2), tindak tutur direktif merupakan tindak tutur yang bertujuan menghasilkan suatu efek berupa tindakan yang dilakukan oleh penutur. Artinya, hasil akhir dari adanya tindak tutur tersebut diharapkan mitra tutur akan melakukan perbuatan yang diminta oleh penutur. 


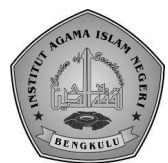

Sementara itu, menurut Agus dan Ngusman (dalam Putri, 2012: 4), tindak tutur direktif merupakan tindak tutur yang berpotensi mengancam citra diri pelaku tutur. Keterancaman ini dapat tertuju, baik kepada penutur maupun mitra tutur. Citra diri penutur dapat jatuh jika perintahnya tidak diperhatikan oleh mitra tutur. Bagi mitra tutur, citra dirinya terancam karena suruhan atau permohonan penutur dapat bersifat membebani, memaksa, atau melecehkan mitra tutur.

Berdasarkan pendapat tersebut, dapat kita simpulkan bahwa tindak tutur direktif adalah jenis tindak tutur yang bertujuan menimbulkan tindakan dari mitra tutur sesuai dengan permintaan ataupun suruhan penutur. Dengan demikian, suatu tindak tutur dapat dikatakan direktif apabila: a) tuturan digunakan untuk menyuruh orang lain melakukan suatu perbuatan, dan b) tuturan menghasilkan suatu efek berupa tindakan mitra tutur. Dalam kehidupan sehari-hari kita sering menemukan penggunaan tindak tutur direktif, baik di rumah, sekolah, kantor, maupun di lingkungan sekitar.

Jenis-jenis tindak tutur direktif sangat bervariasi. Menurut Searle (dalam Huri, 2014: 3) direktif dapat bersifat langsung, yaitu melalui penggunaan kalimat bermodus imperatif dan tidak langsung dengan kalimat bermodus bukan imperatif. Berkaitan dnegan hal tersebut, Searle membagi tindak tutur direktif menjadi menanyakan (ask), memohon (beg), memohon dengan sangat (bid), memerintah (command), menuntut (demand), melarang (forbid), menganjurkan (recommend), dan meminta (request).

Selain Searle, pendapat tentang jenisjenis tindak tutur juga dikemukakan oleh Ibrahim (dalam Etikasari, 2012: 3). Menurut Ibrahim, klasifikasi jenis tindak tutur direktif, meliputi: requestives, questions, requirements, prohibitive, permissive, dan advisories.

Tindak tutur requestives berisi tindak tutur yang mengarah pada meminta, memohon, mengemis, menekan,
Volume 1, Nomor 2, Juli 2019 ISSN 2655-3031 (P), 2655-7851 (O) mengundang, mendoa, mengajak, mendorong. Tindak tutur questions berkaitan dengan menanya, menyelidik, menginterogasi. Requirements berupa membantah, menghendaki, mengkomando, menuntut, mendikte, mengarahkan, menginstruksikan, mengatur, mensyaratkan. Prohibitive merupakan tindak tutur yang berwujud melarang ataupun membatasi. Selanjutnya, tindak tutur permissive seperti menyetujui, membolehkan, memberi wewenang, menganugerahi, membiarkan, mengabulkan, membiarkan, mengizinkan, melepaskan, memaafkan, memperkenankan. Tindak tutur advisories, meliputi menasihati, mengingatkan, mengusulkan, menyarankan, dan mendorong.

Dengan demikian, tindak tutur direktif memiliki beberapa jenis, misalnya menanya, meminta, memerintah, menyuruh, mendesak, membujuk, menghimbau, mengajak, mempersilakan, permintaan izin, mengizinkan, dan melarang. Jenis-jenis tindak tutur direktif tersebut seringkali muncul dalam kehidupan sehari-hari, misalnya saja dalam pembelajaran di sekolah. Meski kedua belas jenis tindak tutur direktif itu tidak selalu hadir dalam percakapan antara guru dan siswa, tapi keberadaannya menunjang pelaksanaan pembelajaran di sekolah.

Tapscott (2013) membagi generasi berdasarkan parameter demografis, dan mempopulerkan istilah generasi $\mathrm{X}, \mathrm{Y}$, dan $\mathrm{Z}$. Karena tulisan ini fokus pada generasi $Y$ (milenial), maka yang akan dibahas lebih banyak adalah generasi tersebut. Menurut Tapscott (2013), ciri khas generasi milenial adalah mudah berinteraksi dengan beragam media hanya melalui alat berlayar ukuran dua inci. Mereka menggunakan ponsel untuk beragam aktivitas. Untuk berbicara, mengecek dan membalas surat elektronik. Mereka menggunakan ponsel untuk kirim pesan, berselancar di dunia maya, bermain game, mencari arah atau jalan, mengambil gambar dan membuat video. Mereka membuka media sosial setiap saat, termasuk 
saat bekerja atau belajar, atau memberitahukan status mereka melalui whatsapp kapan pun mereka mau.

Lebih lanjut menurut Tapscott (2013), meski sama-sama memanfaatkan internet dan ponsel, ada perbedaan norma hidup yang nyata antara generasi milenial dan generasi sebelumnya. Harus diakui bahwa ketergantungan generasi $\mathrm{X}$ terhadap ponsel juga besar. Di sebagian besar wilayah, misalnya, interaksi masyarakat dengan media sosial juga cukup besar. Hanya saja, generasi milenial yang paling melek teknologi dan adaptif dengan segala hal yang berbau informasi. Generasi milenial di Indonesia adalah pemakai media sosial yang fanatik dan kehidupannya sangat terpengaruh dengan perkembangan teknologi. Dalam setiap aktivitas sosial mereka di hampir seluruh provinsi, mereka sangat terbuka dan responsif dengan perkembangan politik dan ekonomi daerahnya. Hal ini tentu berakibat pada sikap mereka yang juga sangat aktif terhadap perubahan lingkungan yang terjadi di sekelilingnya. Mampu menghadapi beragam rintangan dan melihat peluang yang dapat diraih. Oleh karena itulah Tapscott (2013) dalam teorinya mengemukakan bahwa kesadaran modernitas generasi milenial atas nasionalisme tidak lagi bersifat historis melainkan sangat fungsional. Mereka hadir melakukan ekspansi untuk menggantikan generasi sebelumnya. Perubahan dan inovasi selalu dimunculkan untuk membuat sejarah baru. Perbedaan mendasar dan paling mencolok antara generasi milenial dan generasi sebelumnya adalah mereka tumbuh dalam lingkungan saintifik dan serba digital. Melalui gaya hidup yang demikian ini perubahan mendasar pun terjadi di mana hidup menjadi lebih praktis, efisien, dan inovatif. Akhirnya muncullah wajah baru anak muda Indonesia menjadi generasi digital, efisien, terbuka, optimis, inovatif, kritis, dan egaliter.

\section{Metode Penelitian}

ISSN 2655-3031 (P), 2655-7851 (O)

Penelitian ini menggunakan pendekatan penelitian deskriptif kualitatif dengan jenis penelitian mikroetnigrafi merupakan wujud dari pemanfaatan penelitian etnografi bagi peneliti yang bertujuan mendeskripsikan tuturan dalam percakapan di grup whatsapp. Peneliti bertindak sebagai instruments utama. Sumber data penelitian diperoleh dari percakapan antara dosen dan mahasiswa dalam grup whatsapp. Metode pengumpulan data dalam penelitian ini menggunakan metode simak dengan teknik simak bebas libat cakap (SBLC), yaitu peneliti tidak terlibat dalam percakapan dosen dan mahasiswa, peneliti hanya menjadi pengamat penuh dalam penggunaan percakapan dosen dan mahasiswa.

Adapun cara pengumpulan data dalam penelitian ini, yaitu observasi, perekaman, transkrip data, identifikasi data. Selanjutnya untuk menganalisis data,secara teoretis penelitian ini menggunakan model interaktif, yakni sesuai dengan konteks sosial dalam percakapan dalam grup whatsapp (Milles dan Huberman, 1992:20), yaitu melalui perekaman dan mencatat konteks percakapan, transkrip data, identifikasi data, serta penyimpulan. Untuk memeroleh hasil yang diharapkan peneliti melakukan pengecekan keabsahan temuan dengan melakukan ketekunan pengamatan, triangulasi pemeriksaan sejawat melalui diskusi dengan cara mengekspos hasil sementara atau akhir yang diperoleh dalam bentuk diskusi dengan teman-teman sejawat (Moleong,2010:332).

\section{Hasil dan Pembahasan}

Sebagaimana telah penulis paparkan pada bagian tentang jenis-jenis tindak tutur direktif, maka implementasinya dapat kita lihat misalnya saja dalam percakapan grup whatsap anatara dosen dan mahasiwa. Berikut percakapan tindak tutur direktif antara dosen dan mahasiswa dalam grup whatsapp. 


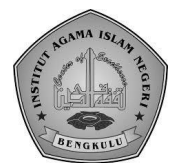

a) Tindak tutur direktif meminta

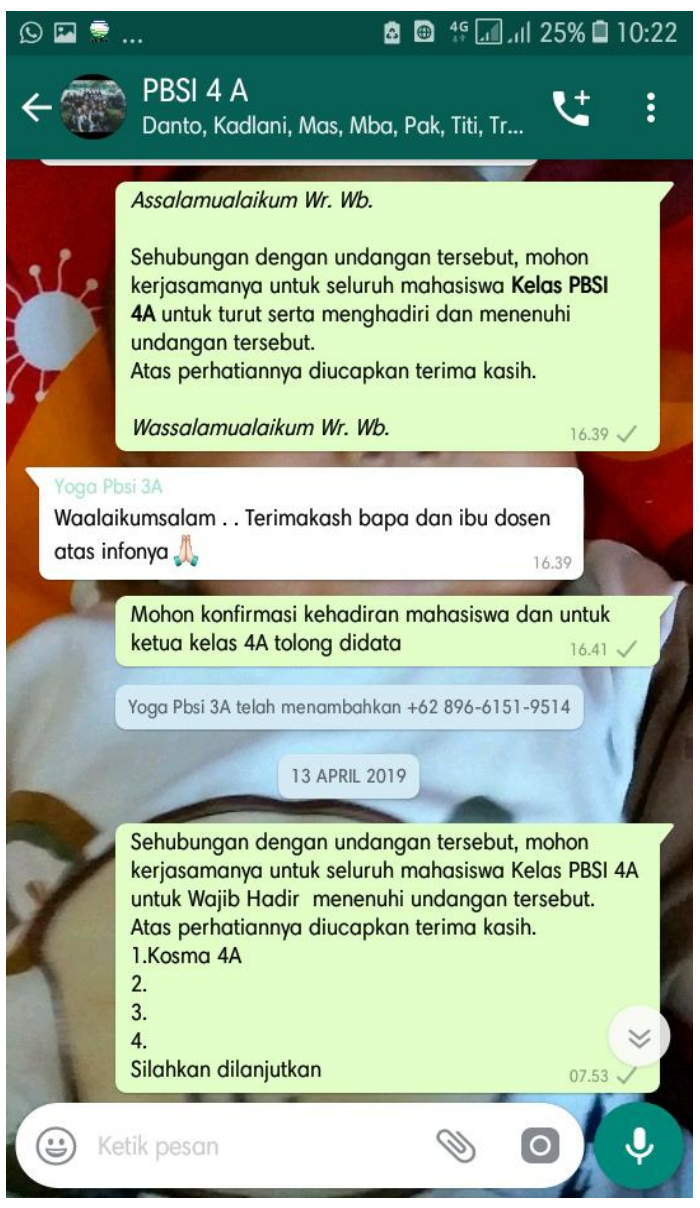

Tindak tutur direktif meminta, tampak ketika dosen meminta agar mahasiswa menghadiri undangan acara kampus, yaitu: "Assalamualaikum wr.wb. Sehubungan dengan undangan tersebut, mohon kerjasama untuk seluruh mahasiwa kelas PBSI 4a untuk turut serta menghadiri dan memenuhi undangan tersebut."
Volume 1, Nomor 2, Juli 2019

ISSN 2655-3031 (P), 2655-7851 (O)

b) Tindak tutur direktif memerintah

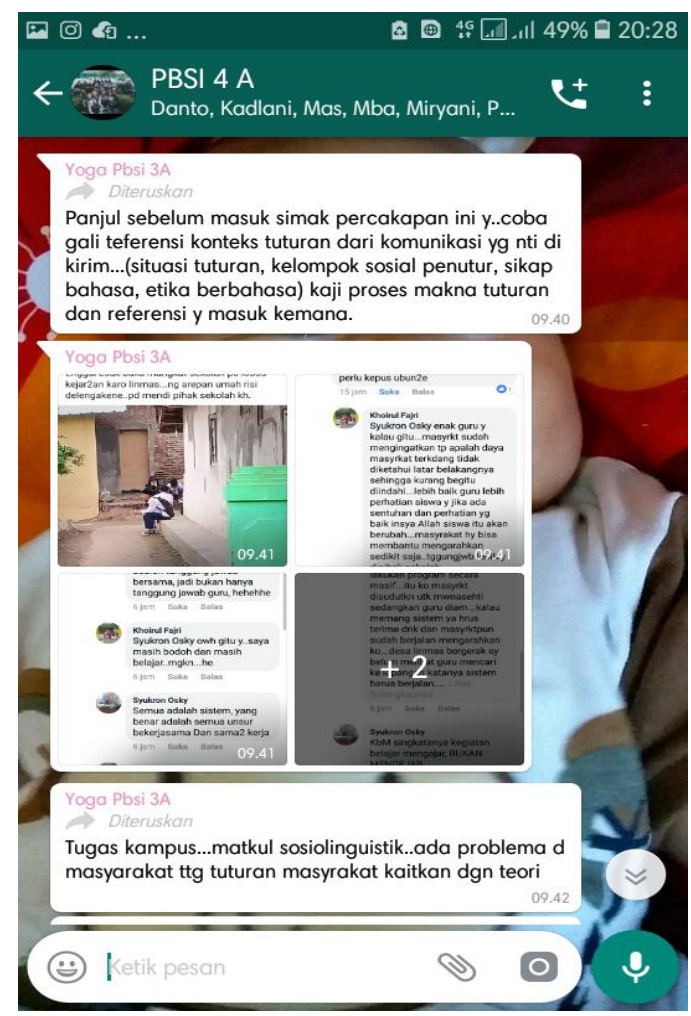

Tindak tutur direktif memerintah, misalnya tampak ketika dosen memberikan tugas kepada mahasiswa pada mata kuliah sosiolinguistik, dosen memerintah agar mahasiswa menyimak percakapan yang diberikan oleh dosen, yaitu: "Panjul sebelum masuk coba simak percakapan ini ya, coba gali referensi konteks tuturan yang nanti dikirim" 


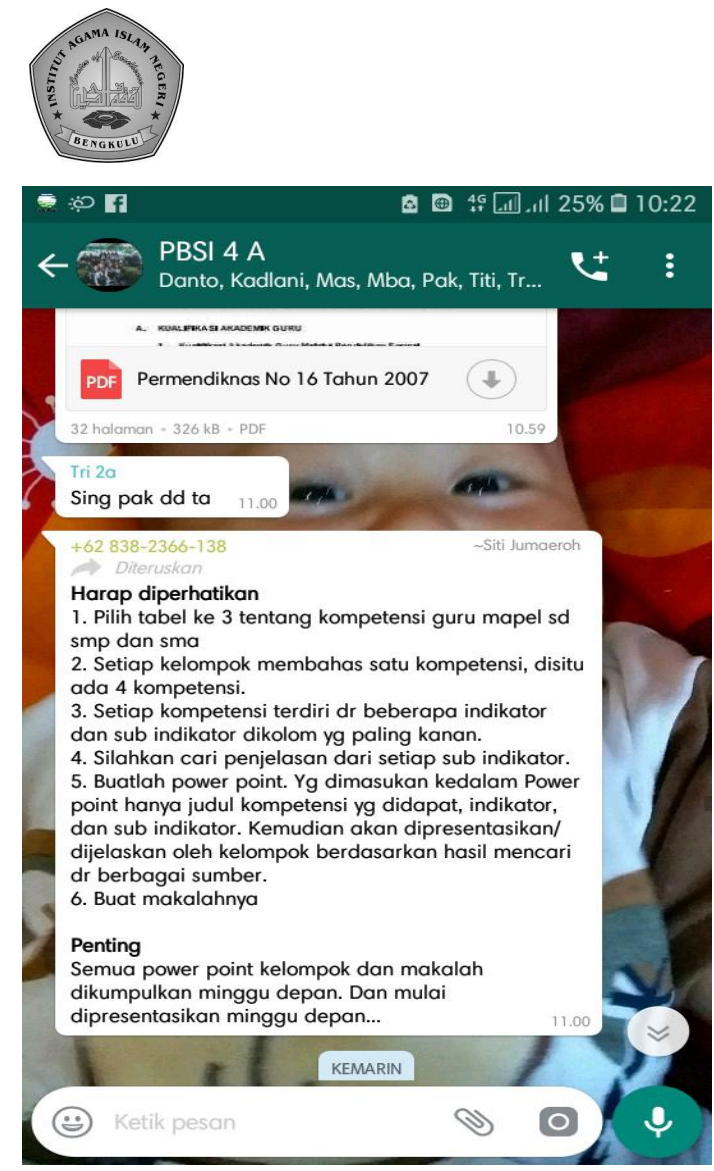

Tindak tutur direktif memerintah juga, tampak ketika dosen memberikan penjelasan dalam memberi tugas kepada mahasiswa: "Harap diperhatikan ....."

c) Tindak tutur direktif menyuruh

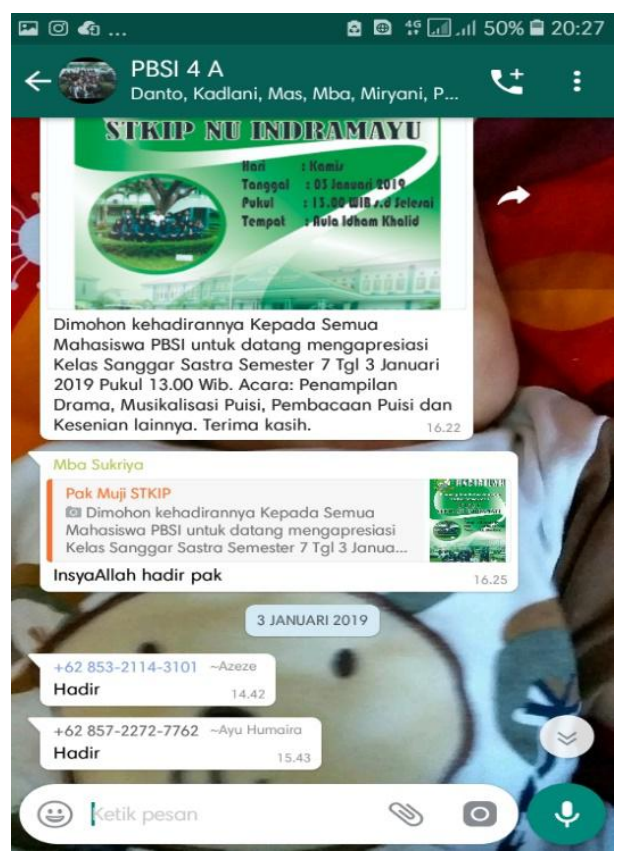

Tindak tutur direktif menyuruh terjadi saat dosen ingin agar semua
Volume 1, Nomor 2, Juli 2019

ISSN 2655-3031 (P), 2655-7851 (O) mahasisiswa PBSI hadir dalam acara kelas sanggar sastra: "Coba, Mas Indra, sebutkan apa saja yang kamu lihat dalam foto tersebut!"

d) Tindak tutur direktif membujuk

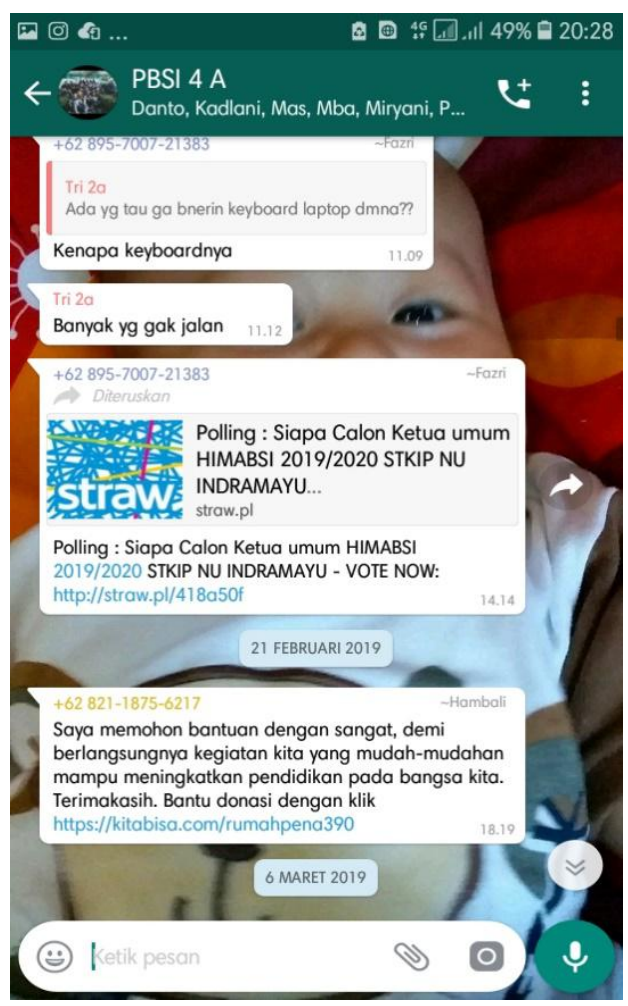

Tindak tutur direktif membujuk, tampak ketika salahsatu mahasiswa agar rekannya dapat memberikan donasi untuk meningkatkan Pendidikan pada bangsa kita, melalui kegiatan yang mereka dirikan: "Saya memohon bantuan dengan sangat, demi berlangsungnya kegiatan kita yang mudah-mudahan mampu meningkatkan pendidikan pada bangsa kita

\section{Simpulan}

Berdasarkan paparan di atas, ada beberapa simpulan tentang tindak tutur direktif, diantaranya sebagai berikut.Tindak tutur direktif adalah tindak tutur direktif adalah jenis tindak tutur yang bertujuan menimbulkan tindakan dari mitra tutur sesuai dengan permintaan ataupun suruhan penutur. Ada beberapa jenis tutur direktif yang muncul dalam percakapan grup whatsapp antara mahasiwa dan dosen, yaitu: 
requestives (meminta), requirements (memerintah), menyuruh, dan membuju.

\section{Daftar Pustaka}

Eliya, Ixsir. 2017. "Model Komunikasi Politik Ridwan Kamil di Medi Sosial Instagram: Kajin Sosiolinguistik". Dialektika. Vol.2, No.4. Tahun 2017. Diakses pada 3 Maret 2019 http://journal.uinjkt.ac.id/index.php/dial ektika/article/view/5540/pdf

Etikasari, Dian. 2012. Tindak Tutur Direktif Dalam Wacana Kelas (Kajian Mikroetnografi Terhadap Bahasa Guru. Universitas Negeri Malang. Diunduh tanggal 25 Maret 2016.

Huri, Taufiqqurrohman. 2014. Analisis Peristiwa Tutur Direktif Kajian Ceramah K.H. Syairozy. Artikel diunduh dari http://ughotudhod.blogspot.co.id/2014/ 01/analisis-peristiwa-tutur-direktif.html

Milles,B. Mathew dan Michael Huberman.1992. Analisis Data Kualitatif Buku Sumber tentang Metode-Metode Baru. Jakarta: UIP.

Moleong.L.J.,2010. Metode Penelitian Kualitatif. Bandung: PT. Remaja Rosdakarya.

Putri, Febrina Riska. 2012. Tindak Tutur Direktif Guru Dalam Pembelajaran Bahasa Indonesia SMA Negeri 15 Padang. Universitas Negeri Padang. Diunduh tanggal 25 Maret 2016.

Rustono. 1999. Pokok-pokok Pragmatik. Semarang: CV IKIP Semarang Press.

Tapscott,D., 2013,Grown Up Digital: yang Muda yang Mengubah Dunia. Jakarta: PT. Gramedia Pustaka Utama. 